\title{
Assessing the Challenges of Pharmaceutical Practices during COVID-19 Pandemic in Nigeria
}

\author{
Nnenna Genevieve Ekechukwu', Kenneth Anele Agu ${ }^{2}$ \\ ${ }^{1}$ Bristol Pharmacy, Gwarimpa, Abuja, Nigeria \\ ${ }^{2}$ Associate Director, Howard University Global Initiative Nigeria, Abuja, Nigeria
}

\begin{abstract}
Pharmacies are the frontline of the pandemic and critical to maintaining public health. The emergence of COVID-19 brought unprecedented challenges and changes to all nations of the world. In the light of this, this study assessed the challenges of pharmaceutical practices in Nigeria during COVID-19. A descriptive cross-sectional survey design was adopted, and the data were collected from 1,200 respondents through the interview schedule and structured questionnaire using a systematic random sampling technique. A total of 1,118 copies of the questionnaire were retrieved, coded, and analysed using descriptive and inferential statistics aided by the SPSS software version 23. The study discovered different factors that influenced the effective practice of pharmacists during the COVID-19 pandemic. The findings of this study revealed that the majority, 591(52.9\%) of the pharmacists, encountered difficulties on the road with security personnel while on essential duty and also found it 'somewhat difficult to work during the pandemic. The results of Factor Analysis grouped the major challenges into material and financial constraints. The results showed two orthogonal factors pharmaceutical practices, which were derived with the total explanation of $65.35 \%$ of the variance. Only variables with constraints loadings of 0.70 and above were used in naming the constraints. The material constraint has the greatest impact on effective practices of pharmacists to provide treatment for illnesses during COVID-19 with a $44.16 \%$ contribution. There is a need for government and institution supports for better and effective pharmaceutical practices before, during, and after any sort of pandemic, especially in drugs supplies and financial assistance.
\end{abstract}

Keywords: Assessment, Challenges, COVID-19 Pandemic, Pharmaceutical Practices, Nigeria.

\section{Introduction}

The Coronavirus disease 2019 (COVID-19), declared and recognized as a global health emergence and a global pandemic by [1-3], is a communicable disease caused by the newly discovered Severe Acute Respiratory Syndrome Coronavirus 2 (SARS-CoV-2). Coronaviruses are also described as zoonotic, as they are usually transmitted between animals and man through direct contact with an infected person $[4,5]$. COVID-19 pandemic was primarily discovered in Wuhan, China, and reported to World Health Organization (WHO) in December 2019 [6, 7]. In December 2019, the emerging infectious disease called the novel coronavirus (COVID-19) outbreak, began and spread worldwide [8]. The emergence of novel Coronavirus disease (COVID-19) since late 2019 introduced a global health crisis that has revealed the present-day health systems limits globally [6]. Though, studies have stated that coronavirus was first identified in 1937 as an infectious bronchitis virus with which birds suffered that devastated poultry stocks [5]. In the past 70 years, studies have found camels, cattle, cats, dogs, horses, mice, pigs, rats, and turkeys that were infected with coronaviruses [5]. Respiratory syndrome coronavirus (MERS$\mathrm{CoV})[\mathrm{WHO}, 2020]$ and Severe Acute 
Respiratory Syndrome (SARS) are mainly caused by coronaviruses [WHO, 2020]. The most common symptoms of coronavirus in patients are fever, dry cough, and respiratory problems [8]. It was reported that $80 \%$ of the infected cases are mild or asymptomatic [8]. The descriptions of clinical signs and symptoms of coronavirus disease and advice on preventive behaviors have historically been passed from one generation to another, helping to shape many religious and socio-cultural conventions [7].

The increasing numbers of infectious cases overwhelmed the workload in healthcare sectors in different countries [11]. The pandemic brought unprecedented challenges and changes to all the nations of the world (including Nigeria). For example, unprecedented mortality, distress, and mental resilience are some of the challenges posed by the COVID-19 pandemics [3, 12, 13]. In Africa, it was reported that confirmed cases of COVID-19 rose to $1,203,769$ and 28,289 deaths as of $25^{\text {th }}$ August 2020 [14]. The Federal Ministry of Health reported the first case of COVID-19 in Nigeria on February 27, 2020, in Lagos [15]. Since that period, there has been a drastic increase in the number of daily reported cases in the country, with 166,682 confirmed cases and 2,117 deaths as of June 3, 2021 [16]. In spite of the fact that Nigeria is the most populous country in Africa, the country had about $2.7 \%$ confirmed cases and $1.8 \%$ death of COVID-19 in the region as of the second quarter of 2020 [17].

Since Nigeria solely depends on importation to meet its demands, the country suffered a huge blow to several sectors, including the pharmaceutical industry. Even though the local industry in Nigeria fairs better when compared to its counterparts in other developing countries in Sub-Saharan African [15]. In March 2020, when the COVID-19 pandemic had a tremendous effect on every sector of the economy, especially the pharmaceutical sector and practices as well as the health and market economy, strict measures were taken, most importantly the lockdown measure. Consequently, the pandemic affected the economy by directly affecting production in major countries that are sole manufacturers of raw materials, intermediate products, and consumer goods, thereby creating supply chain and market disruption, and by its financial impact on firms and the financial markets.

As part of the emergency response activities across all States in Nigeria, health education campaigns were directed at members of the public [17, 18]. In spite of all the basic precautionary and/or preventive measures put in place to curb the spread of COVID-19, pharmaceutical practices and other health care professionals faced some challenges in one way or the other during the pandemic. Studies have shown the impacts of COVID-19 in every region and/or continent of the world, especially in America, Europe, and Asia [19, 20].

In Nigeria, studies have been conducted on COVID-19 [15, 17, 21-27]. From these previous studies, little or no studies have been conducted on the challenges facing pharmaceutical practices during COVID-19 in Nigeria. This study filled this gap by assessing the challenges of pharmaceutical practices in Nigeria during COVID-19 with a view to illuminating areas of strengths and weaknesses for future improvement.

\section{Pharmacy and Pharmaceutical Practices}

Pharmacists are critical for attaining the goal of universal health coverage and equitable access to essential health services, particularly in relation to access to medicines and medicines expertise [28]. Pharmacists, the third largest and most accessible healthcare professionals in the world [2, 29], are often the first point of contact with the health system in many countries [30, 31]. Pharmacists are central to attaining the goal of equitable access and rational use of medicines - a key objective of universal health coverage [32]. 
Pharmacies are regarded as the frontline of the pandemic and critical to maintaining public health. Pharmacy and Pharmacy Practice. In recent years, pharmacy, like other health professions, has undergone a change in the way it is practiced because of technological advances and the changes in the nature of health care delivery [33]. Pharmacy practice serves to facilitate the appropriate use of medicines. In traditional approaches to clinical pharmacy, it was thought that this could be achieved by helping to ensure that individual patients received the 'correct medicine in the correct dose at the correct time'.

\section{Materials and Methods}

The study area is Nigeria. It lies between latitudes $4 \mathrm{o}$ and $14 \mathrm{o}$ North of the equator and longitudes 20 42' and $15^{\circ} 00^{\prime}$ East of the Greenwich Meridian (Figure 1) [34]. In 2016, the population of the study area was put at 193,392,517 [35]. The study area comprises the Federal Capital Territory (FCT, Abuja) and 36 states that are subdivided into 774 Local Government Areas (LGAs) [36]. The study area was based on the six geo-political regions (including FCT) (Figure 1). Infectious diseases such as malaria, HIV/AIDs, and tuberculosis are leading causes of death in the country [37]. Although current estimates indicate improvement in under-five and maternal mortality rates between 1990 and 2012 in Nigeria, these are still significantly high at $117 / 1000$ and 560/100,000 live births, respectively, compared to other countries in the SSA region [37].

Evidence also indicates an increasing prevalence of non-communicable and chronic diseases, including diabetes, hypertension, cardiovascular diseases, and stroke in the country [38-40]. Overall health status and access to healthcare vary across the different regions in the country, with existing reports suggesting that health indicators are generally worse in the northern region compared to the Southern [41].
The study adopted a descriptive crosssectional survey designed specifically to elicit information from the respondents among the targeted population. The research instrument was a standardized structured (close-ended) and unstructured (open-ended) self-administered and electronic questionnaire to collect data. The questionnaire was tested to establish its validity and reliability. The researcher passed the questionnaire through experts and public health professional researchers to appraise the relevance of the questions in relation to the topic to determine if it would test what it was intended for. This tool was furthermore pretested before being administered. 1,200 professional and practice pharmacists in hospital practice, community practice, and industrial practice were systematically and randomly selected across the six geo-political zones in Nigeria. A total of 1,118 copies of the questionnaire were retrieved, coded, and analyzed using descriptive and inferential statistics, while the Statistical Package for Social Sciences (SPSS) software version 23 was used to run the analyses. Descriptive statistics include the use of frequency, percentages, mean, and standards deviation, while inferential statistics include exploratory factor analysis. The researcher ensured that all the administered copies of the questionnaire were collected, checked, and coded in an excel Microsoft package. The reliability coefficient of the questionnaire was assessed. Mean scores and standard deviations analysis procedures were used for the challenges facing pharmaceutical practices in the study area. The challenges facing pharmaceutical practices were further subjected to exploratory factor analysis. Factor analysis is a technique of data reduction used to collate a huge quantity of observed items statistically into a lesser set of latent variables termed factors due to their fundamental bivariate correlation patterns [42, 43]. Exploratory factor analysis procedure using the principal factor model with iteration and varimax rotation was further employed in 
grouping the constraints variables into major of 0.70 and above were used in naming the factors. However, only variables with loadings factors.

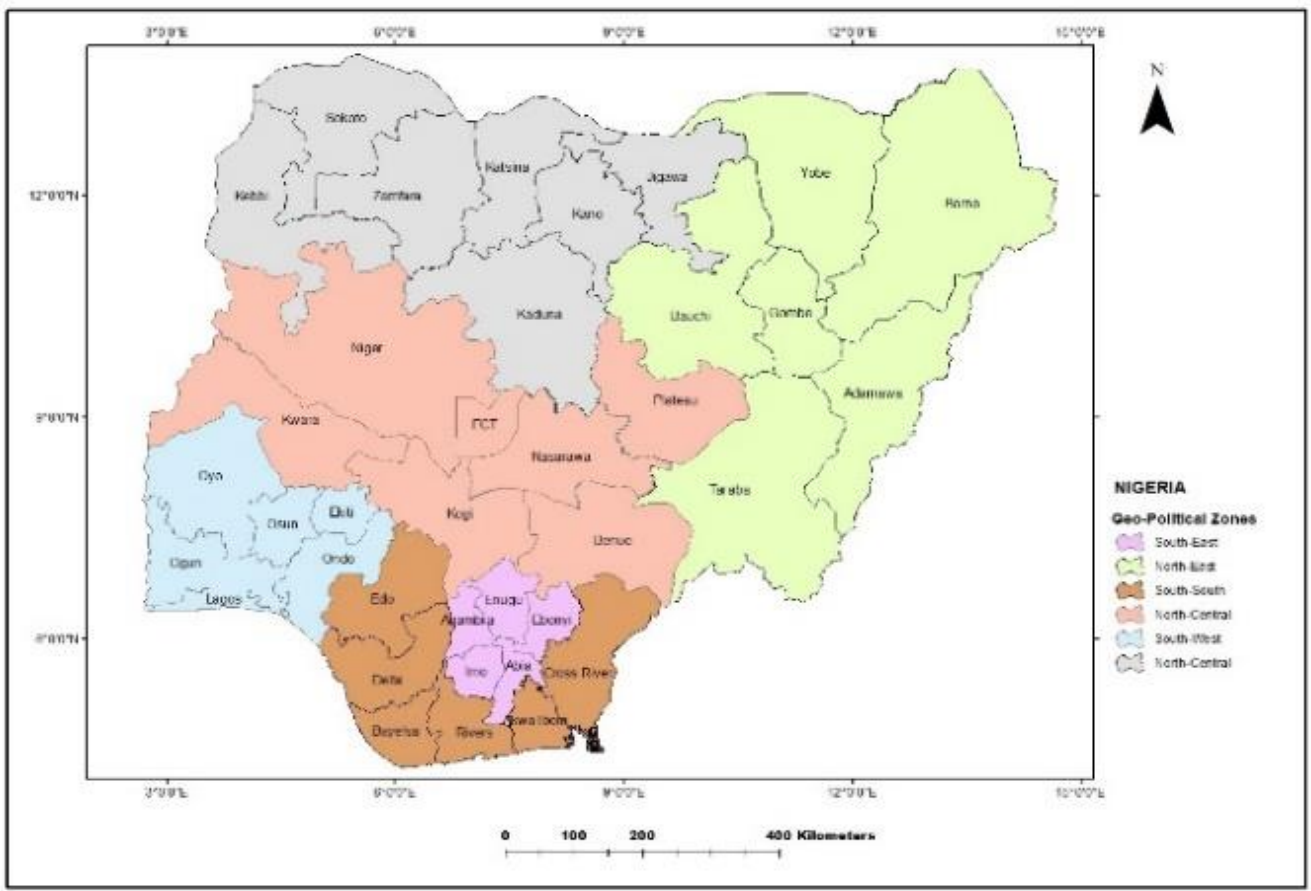

Figure.1. Map of the Study Area, Nigeria

\section{Results}

\section{Demographic Characteristics of the Respondents}

Table 1 presents the socio-demographic characteristics of the respondents in the study area are presented.51.4\% of the respondent were male.

The respondents between 30 and 59 years constituted the larger population of $84 \% .81 .2 \%$ of the respondents were married in the study area, while all the respondents were professional pharmacists with university educational qualifications; $42.5 \%$ with Bachelor of Pharmacy, 25.8\% with Master degree, and
6.3\% with Ph.D. degrees. Hospital practice, community practice, and industrial, pharmaceutical practice constituted the larger population of the respondents of $51.2 \%, 1.9 \%$, and $7.2 \%$, respectively.

Health insurance, marketing/production, administrative, political, and non-Governmental organizations were other areas of pharmaceutical practice. Those pharmacists (respondents) who had spent between 20 and 24 years constituted $21.3 \%$ (Table 1). The majority, $722(64.6 \%)$ of the respondents (Pharmacists) in the study area, worked for 6-8 hours per day.

Table 1. Demographic Characteristics of the Respondents

\begin{tabular}{|l|l|l|l|}
\hline Variables & Frequency & Percent (\%) \\
\hline \multirow{4}{*}{ Gender } & Male & 575 & 51.4 \\
\cline { 2 - 4 } & Female & 513 & 45.9 \\
\cline { 2 - 4 } & Prefer not to say & 30 & 2.7 \\
\cline { 2 - 4 } & Total & $\mathbf{1 1 1 8}$ & $\mathbf{1 0 0 . 0}$ \\
\hline \multirow{4}{*}{ gge Bracket } & $18-29$ & 130 & 11.6 \\
\cline { 2 - 4 } & $30-39$ & 256 & 22.9 \\
\cline { 2 - 4 } & $40-49$ & 357 & 31.9 \\
\hline
\end{tabular}




\begin{tabular}{|c|c|c|c|}
\hline & $50-59$ & 326 & 29.2 \\
\hline & $60-69$ & 49 & 4.4 \\
\hline & Total & 1118 & 100.0 \\
\hline \multirow[t]{4}{*}{ Marital Status } & Single & 200 & 17.9 \\
\hline & Married & 908 & 81.2 \\
\hline & Separated & 10 & 0.9 \\
\hline & Total & 1118 & 100.0 \\
\hline \multirow[t]{6}{*}{ Educational Level } & B. Pharm & 475 & 42.5 \\
\hline & Masters & 288 & 25.8 \\
\hline & Postgraduate Fellowship & 255 & 22.8 \\
\hline & $\mathrm{PhD}$. & 70 & 6.3 \\
\hline & Others & 30 & 2.7 \\
\hline & Total & 1118 & 100.0 \\
\hline \multirow[t]{7}{*}{ Area of Practice } & Academia & 10 & 0.9 \\
\hline & Hospital & 572 & 51.2 \\
\hline & Community & 357 & 31.9 \\
\hline & Industrial & 80 & 7.2 \\
\hline & Public Health & 69 & 6.2 \\
\hline & Others & 30 & 2.7 \\
\hline & Total & 1118 & 100.0 \\
\hline \multirow{8}{*}{ Other Areas of Practice } & Do not practice in any other area & 1008 & 90.2 \\
\hline & NGO & 10 & 0.9 \\
\hline & Health Insurance & 40 & 3.6 \\
\hline & Marketing/Production & 20 & 1.8 \\
\hline & Academia & 20 & 1.8 \\
\hline & Administrative & 10 & 0.9 \\
\hline & Politics & 10 & 0.9 \\
\hline & Total & 1118 & 100.0 \\
\hline \multirow[t]{8}{*}{ Years of Practice } & Less the 5 Years & 179 & 16.0 \\
\hline & $5-9$ Years & 79 & 7.1 \\
\hline & $10-14$ Years & 268 & 24.0 \\
\hline & $15-19$ Years & 108 & 9.7 \\
\hline & $20-24$ Years & 238 & 21.3 \\
\hline & $25-29$ Years & 157 & 14.0 \\
\hline & 30 Years and above & 89 & 8.0 \\
\hline & Total & 1118 & 100.0 \\
\hline \multirow{5}{*}{$\begin{array}{l}\text { Average number of } \\
\text { daily hours of work }\end{array}$} & 3 - 5 Hours & 20 & 1.8 \\
\hline & $6-8$ Hours & 722 & 64.6 \\
\hline & $9-11$ Hours & 277 & 24.8 \\
\hline & 12 Hours and Above & 99 & 8.9 \\
\hline & Total & 1118 & 100.0 \\
\hline
\end{tabular}




\section{Challenges Faced by Pharmacists and Pharmaceutical Practices during Covid- 19}

Table 2 and Figure 2 present the difficulties encountered by pharmacists during COVID-19 in the study area. The results showed that $52.9 \%$ of the pharmacists encountered difficulties on the road with security personnel while on essential duty. As a result, only $8.1 \%$ of the respondents indicated that it was very difficult for them to work during the COVID19 pandemic, while the majority 513(45.9\%) indicated 'somewhat difficult to work during COVID-19 pandemic in the study area (Table $3)$.

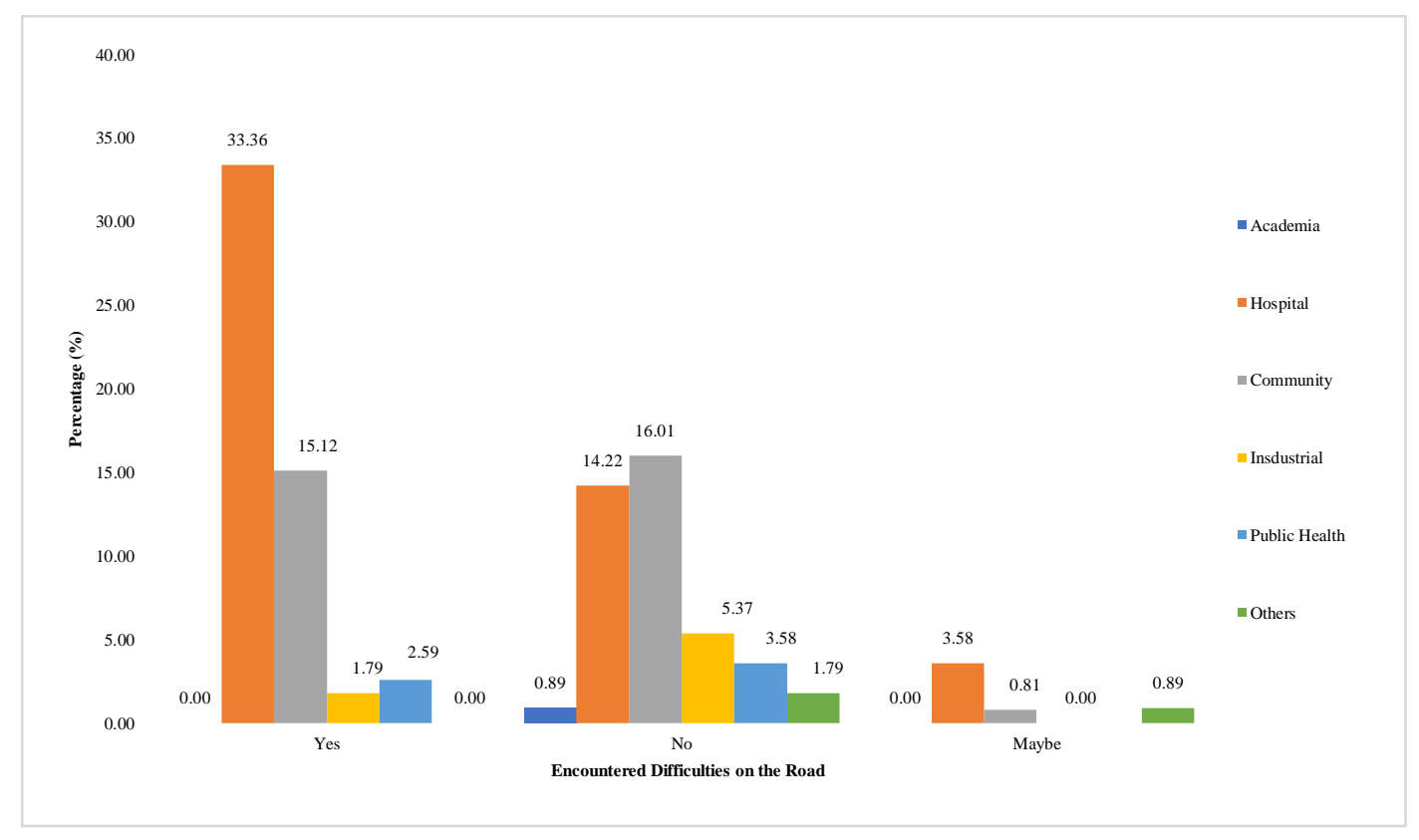

Figure 2. Difficulties Encountered on the Road by the Respondents during COVID-19 Pandemic

Table 2. Statistics of the Difficulties Encountered on the Road during COVID-19

\begin{tabular}{|l|l|l|l|l|l|l|l|}
\hline & \multicolumn{4}{|l|}{ Area of Practice } & \multirow{2}{*}{ Total } \\
\cline { 2 - 7 } & Academia & Hospital & Community & Industrial & $\begin{array}{l}\text { Public } \\
\text { Health }\end{array}$ & Others & \\
\hline Yes & $0(0.0)$ & $373(33.36)$ & $169(15.12)$ & $20(1.79)$ & $29(2.59)$ & $0(0.0)$ & $591(52.86)$ \\
\hline No & $10(0.89)$ & $159(14.22)$ & $179(16.01)$ & $60(5.37)$ & $40(3.58)$ & $20(1.79)$ & $468(41.86)$ \\
\hline Maybe & $0(0.0)$ & $40(3.58)$ & $9(0.81)$ & $0(0.0)$ & $0(0.0)$ & $10(0.89)$ & $59(5.28)$ \\
\hline Total & $10(0.89)$ & $572(51.16)$ & $357(31.93)$ & $80(7.16)$ & $69(6.17)$ & $30(2.68)$ & $1118(100)$ \\
\hline
\end{tabular}

Table 3. How Difficult it was to Work during COVID-19 in Pharmaceutical Practices

\begin{tabular}{|l|l|l|l|l|l|l|l|}
\hline & \multicolumn{2}{|l|}{ Area of Practice } & Total \\
\cline { 2 - 7 } & Academia & Hospital & Community & Industrial & $\begin{array}{l}\text { Public } \\
\text { Health }\end{array}$ & Others & \\
\hline $\begin{array}{l}\text { Very } \\
\text { Difficult }\end{array}$ & 0.0 & $50(4.47)$ & $20(1.79)$ & 0.0 & $20(1.79)$ & 0.0 & $90(8.05)$ \\
\hline Very Easy & 0.0 & $29(2.59)$ & $49(4.38)$ & 0.0 & 0.0 & $20(1.79)$ & $98(8.77)$ \\
\hline $\begin{array}{l}\text { Somewhat } \\
\text { Easy }\end{array}$ & $10(0.89)$ & $109(9.75)$ & $109(9.75)$ & $20(1.79)$ & $40(3.58)$ & 0.0 & $288(25.76)$ \\
\hline
\end{tabular}




\begin{tabular}{|c|c|c|c|c|c|c|c|}
\hline & & & & & & & \\
\hline & & & & & & & \\
\hline 10 & & & & & & & \\
\hline \multicolumn{4}{|c|}{$\begin{array}{l}\text { A larger percentage }(86.6 \%) \text { of the } \\
\text { respondents encountered poor patronage, } \\
\text { shortage of cash flow }(85.7 \%) \text {, and shortage of } \\
\text { drugs/medication, and the high cost of raw } \\
\text { materials as well as other consumables with a } \\
\text { percentage of } 83.98 \% \text { (Figure } 3 \text { ). The mean and } \\
\text { standard deviation results of the challenges are } \\
\text { also presented in Table } 4 \text {, where a shortage of } \\
\text { raw materials (mean }=1.31 \text { ), high cost of raw }\end{array}$} & \multicolumn{4}{|c|}{$\begin{array}{l}\text { materials (mean }=1.21) \text { shortage of } \\
\text { drugs/medications (mean=1.21), and shortage } \\
\text { of cash flow (1.20) are the major challenges } \\
\text { faced by pharmaceutical practices in the study } \\
\text { area. Other challenges encountered by the } \\
\text { respondents during the COVID-19 pandemic } \\
\text { include food and house maintenance supplies, } \\
\text { restriction from teaching and research, and the } \\
\text { fear of getting the infection. }\end{array}$} \\
\hline
\end{tabular}

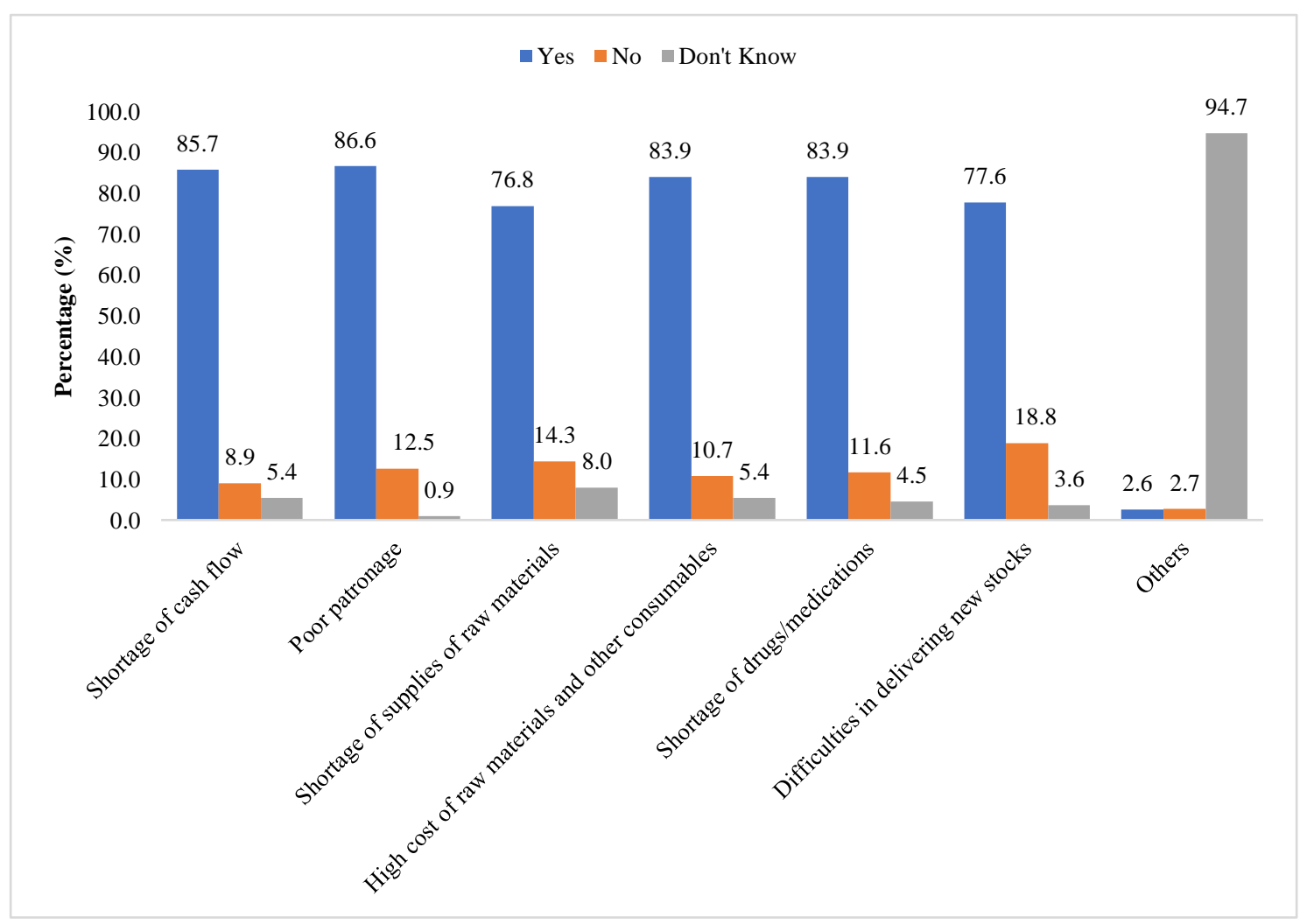

Figure 3. Challenges Faced by Pharmaceutical Practices during COVID-19 Pandemic

Table 4. Statistics of the Challenges Faced by Pharmaceutical Practices $(n=1118)$

\begin{tabular}{|l|l|l|}
\hline Challenges Encountered & Mean & Std. Deviation \\
\hline Shortage of cash flow & 1.1968 & 0.51539 \\
\hline Poor patronage & 1.1431 & 0.37503 \\
\hline Shortage of supplies of raw materials & 1.3051 & 0.61072 \\
\hline High cost of raw materials and other consumables & 1.2147 & 0.52552 \\
\hline Difficulties in delivering new stocks & 1.2594 & 0.51371 \\
\hline Shortage of drugs/medications & 1.2057 & 0.50306 \\
\hline
\end{tabular}

${ }^{1}$ Ranged from 1 "Yes" to 3 "Don't Know." 
The results of the rotated component matrix showing the extracted factors based on the responses of respondents are shown in Table 5. The results showed two orthogonal factors in the challenges faced by pharmaceutical practices in the study area, which were derived with the total explanation of $65.35 \%$ of the variance. Only variables with constraints loadings of 0.70 and above were used in naming the constraints. The Eigenvalues, percentage of variance, and cumulative percentage of the variance explained are also presented in Table 5.

Table 5. Challenges Encountered during COVID-19 Pandemic

\begin{tabular}{|l|l|l|}
\hline Items Description & Factor 1 & Factor 2 \\
\hline Shortage of supplies of raw materials & 0.839 & -0.004 \\
\hline Shortage of drugs/medications & 0.8 & 0.146 \\
\hline $\begin{array}{l}\text { High cost of raw materials and other } \\
\text { consumables }\end{array}$ & 0.745 & 0.227 \\
\hline Shortage of cash flow & -0.103 & 0.874 \\
\hline Poor patronage & 0.286 & 0.78 \\
\hline Difficulties in delivering new stocks & 0.438 & 0.54 \\
\hline Factor Description & Materials & Financial \\
\hline Eigenvalues & 2.650 & 1.271 \\
\hline \% of Variance & 44.161 & 21.191 \\
\hline Cumulative \% of Variance Explained & 44.161 & 65.352 \\
\hline
\end{tabular}

Extraction Method: Principal Component Analysis

Rotation Method: Varimax with Kaiser Normalization

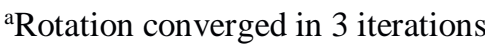

The factor I is tagged "materials constraint". These two factors or constraints have an impact on pharmacists and/or pharmaceutical practices in Nigeria. The eigenvalue of Factor I is 2.65, with $44.16 \%$ of the variance. The factor I have very high significant loading on the variable 'shortage of supplies of raw materials (0.84), "shortage of drugs/medications" (0.80), and moderately high loading on the variables 'high cost of raw materials and other consumables (0.75).

Factor II, which is tagged "financial constraint", has an Eigenvalue of 1.23 and contributed $21.19 \%$ to the variance in the challenges of pharmaceutical practices in the study area. Factor II has the highest loading on 'shortage of cash flow' and 'Poor patronage' with loading points 0.87 and 0.78 respectively.

The finding of this study further showed that $46.06 \%$ of the respondents in the pharmaceutical practices faced a shortage of staff/personnel in the study area (Table 6). Hospital pharmaceutical practice faced a $31.84 \%$ shortage of staff/personnel; community practice faced a $9.75 \%$ shortage of staff, while industrial practice, public health practice, and academia faced smaller percentages of shortage of staff during COVID-19 in the study area.

The rationale behind the shortage of staff/personnel in the pharmaceutical practices during COVID-19 is presented in Figure 4. 'Staff infected with COVID-19' was indicated by the majority $(26.0 \%)$ of the respondents as the main reason for the shortage of staff during COVID-19.

Furthermore, respondents revealed that 'government directives/orders for junior staff to stay at home, 'family pressure to stay at home, and 'the anxiety among the staff of being infected with the viruses were indicated as the minor reasons for the shortage of staff during COVID-29. The restriction of staff to move 
around during the COVID-19 pandemic was pharmaceutical practices during COVID-19, as not a reason for the shortage of staff in the indicated by the respondents.

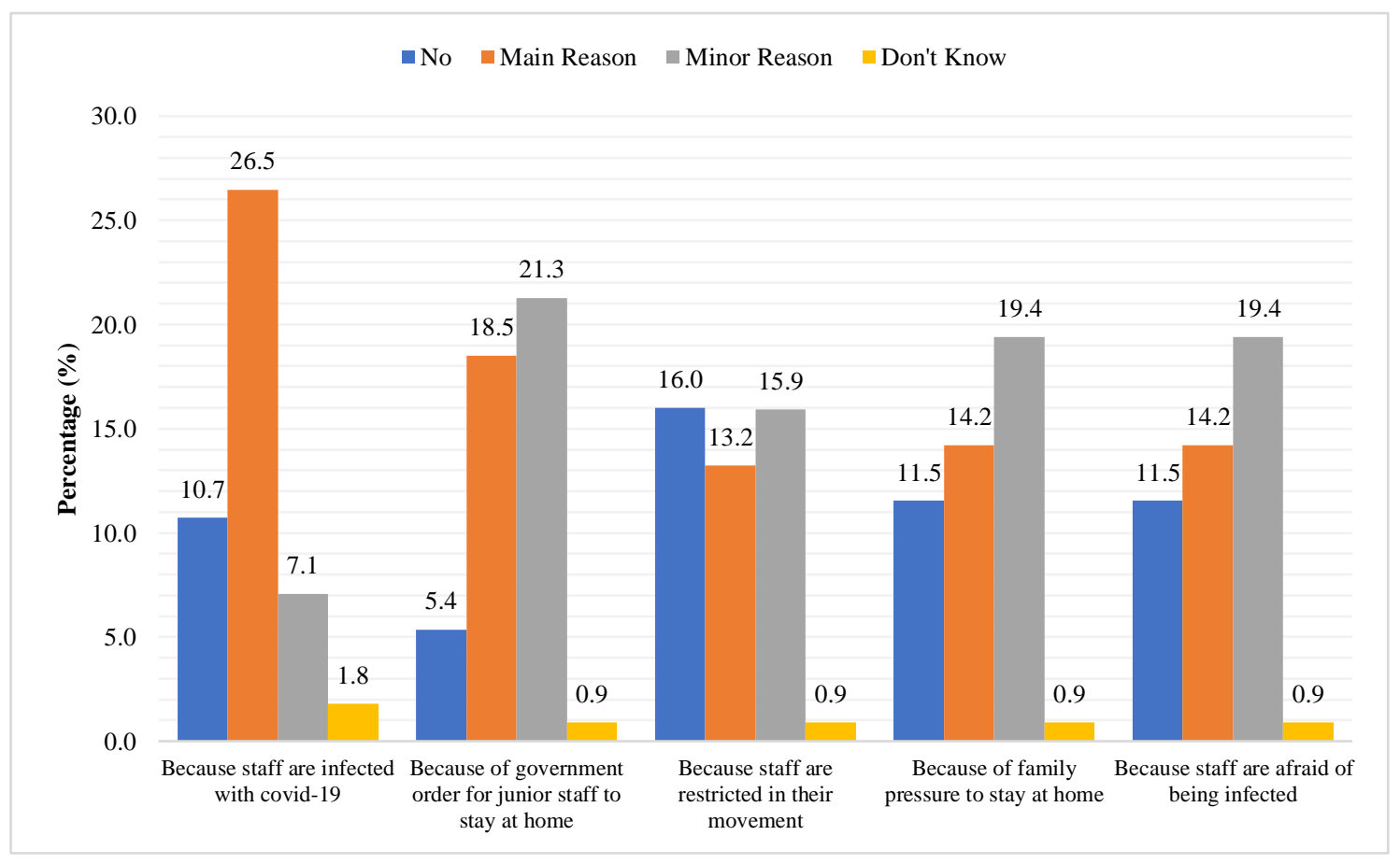

Figure 4. Perception on the Major Reasons for the Shortage of Staff/Personnel in the Pharmaceutical Practices during COVID-19

Table 6. Shortage of Staff in Pharmaceutical Practices during COVID-19

\begin{tabular}{|l|l|l|l|l|}
\hline & Yes & No & Maybe & \\
\hline Academia & 0.0 & $10(0.89)$ & 0.0 & $10(0.89)$ \\
\hline Hospital & $356(31.84)$ & $196(17.53)$ & $20(1.79)$ & $572(51.16)$ \\
\hline Community & $109(9.75)$ & $248(22.18)$ & 0.0 & $357(31.93)$ \\
\hline Industrial & $10(0.89)$ & $70(6.26)$ & 0.0 & $80(7.16)$ \\
\hline Public Health & $20(1.79)$ & $49(4.38)$ & 0.0 & $69(6.17)$ \\
\hline Others & $20(1.79)$ & $10(0.89)$ & 0.0 & $30(2.68)$ \\
\hline Total & $515(46.06)$ & $583(52.15)$ & $20(1.79)$ & $1118(100)$ \\
\hline
\end{tabular}

\section{Discussion}

Findings of this study revealed that pharmacists encountered difficulties on the road with security personnel while on essential duty, and only $8.1 \%$ of the respondents indicated that it was very difficult for them to work during the COVID-19 pandemic. The difficulties encountered on the road while on essential duties might be attributed to the directives given by the government to the law enforcement agencies during the lockdown approach in the study area. In contrast to the findings of a previous study, two-third of the respondents found it somewhat difficult or very difficult to work effectively during the COVID19 pandemic [25].

Studies suggest that healthcare workers are at higher risk of infection when treating patients with COVID-19 [8]. They are also vulnerable to physical and emotional exhaustion [44] as well as the development of various mental health disorders [8]. This fact is confirmed by the higher grades of mental health symptoms reported throughout the pandemic [45]. Some of the challenges faced by the pharmaceutical practices include poor patronage, shortages of cash flow, shortage of drugs/medication, and 
the high cost of raw materials. The challenges faced by the pharmaceutical practices could be a result of the restrictions of the economic activities and other contributing factors. The most common challenges that pharmacy professionals faced during COVID-19 were general anxiety about the impact of coronavirus on their life, and difficulties with communication with their co-workers, issues with internet connectivity, social isolation, to mention but a few $[3,8,11,12,25]$. All these afore-mentioned challenges faced by the pharmacists and/or pharmaceutical practices during the COVID-19 pandemic were grouped into two constraints factors, namely 'material constraints' and 'financial constraints'.

Hospital and community pharmaceutical practices faced the larger percentages of shortage of staff/personnel, which might be a result of the impact of the COVID-19 pandemic in the study area. The shortage of staff/personnel was due to the fear that some staff got infected with the virus, 'government directives/orders for junior staff to stay at home, 'family pressure to stay at home, and 'the anxiety of being infected with the viruses was indications of the shortage of staff in the study area.

The need for organizational and government supports is imperative for improving pharmaceutical practices in the study area. The ranking of 'online personnel training'; 'advice on how to prevent infections while maintaining all business operations and interstate movement'; 'adequate provision of work tools; training on diversification of products, services, and sales channels; and 'online management training' as their 1st priority needed as organizational supports is to better improve the profession and pharmaceutical practices to respond to the COVID-19 pandemic and other infectious diseases in the study area. This finding is similar to the findings, which stated that webinars on COVID-19, access to a community of support to share questions and concerns, and signposting to information are also important supports to better improve the pharmaceutical practices in the study area [25]. Not only organizational supports are needed for better improvement but also government supports.

\section{Conclusion}

The pharmaceutical practices and pharmaceutical healthcare professionals of Nigeria have shown to be contributing to the healthcare sector, especially with the emergence of COVID-19, which negatively affected pharmacists and pharmaceutical practices in the country. Many factors also affect the quality of health services provided by pharmacists, which include but are not limited to human resources, materials, and finances. As human resource is a vital component in delivering health services, pharmacists play significant roles in improving the health status of Nigerians. In this respect, the challenges of pharmaceutical practices during the COVID-19 Pandemic in Nigeria were assessed. This work has thrown more light on the difficulties and/or challenges faced by the pharmacists during COVID-19 and the needed supports for better improvement of pharmaceutical practices and lives of pharmaceutical professionals in Nigeria. This study recommends that government efforts should be made to lessen the total manufacturing and distribution costs of drugs; make access to cash/short-term finances available to pharmacists without all the bottleneck processes and long protocols; approving and implementing friendly production and distribution policies during and after COVID19 pandemic is very crucial.

\section{Conflict of Interest}

We have no conflict of interest to declare.

\section{Acknowledgements}

The author expresses his gratitude to all pharmacists and/or professionals for their willingness and cooperation to participate in this study. 


\section{References}

[1] Ramzy, A., and McNeil, D.G., 2020, World Health Organisation declares global emergency as Wuhan coronavirus spreads. The New York Times. Accessed: 30/01/2020. https://nyti.ms/2RER70M.

[2] The New York Times, 2020, Nigeria Responds to First Coronavirus Case in Sub-Saharan Africa. 28 March 2020.

[3] Roy, R.M. et al. 2021, Psychological distress during pandemic Covid-19 among adult general population: Result across 13 countries. Clinical Epidemiology and Global Health, 10 (2021), 100708, 1-6.

https://doi.org/10.1016/j.cegh.2021.100708.

[4] Weiner, L.P., 1987, Coronaviruses: A historical perspective. In Michael, M.C.L. and Stephen, A.S. (Eds), Corona Viruses: Advances in Experimental Medicine and Biology (pp. 1-4), volume 28, Plenum Press: New York and London.

[5] International Medical Aids-IMA, 2020, Coronavirus: What you need to know. 21 April 2020. Retrieved 25 April 2020 at https://medicalaid.org/.

[6] World Health Organisation, 2020, Infection prevention and control for the safe management of a dead body in the context of COVID-19 Interim guidance 24 March 2020.

[7] Shakespeare, M., 2002, Zoonoses. London, U.K.: Pharmaceutical Press, Division of the Royal Pharmaceutical Society.

[8] Lai, J., Ma, S., Wang, Y., Cai, Z., Hu, J., Wei, N., et al. 2020, Factors associated with mental health outcomes among health care workers exposed to coronavirus disease 2019. JAMA Netw Open, 3: e203976.

Doi:10.1001/ jamanetworkopen.2020.3976.

[9] World Health Organization, 2020, Middle East respiratory syndrome coronavirus (MERS-CoV). Available: https://www.who.int/emergencies/merscov/en/ Accessed: 8 September 2021.

[10]WHO, 2020, Severe Acute Respiratory Syndrome (SARS) Available: https://www.who.int/csr/sars/en/ Accessed: 7 September 2021.

[11] Mila, N.N.H., Roy, R.M., Ayesha, A., Fatjona, K., Radwa, A.E., Jeldah, M.N., and Adinegara, L.A.,
2020, Immediate impact of COVID-19 on mental health and its associated factors among healthcare workers: A global perspective across 31 countries. Viewpoints, 10(2), 020381, 1-6. doi: 10.7189/jogh.10.020381.

[12]WHO, 2020, Mental health and psychosocial considerations during the COVID-19 outbreak. https://www.who.int/docs/default-

source/coronaviruse/mental-healthconsiderations.pdf?sfvrsn=6d3578af_2;2020.

[13]Zhu N, Zhang D, Wang W, et al. A novel coronavirus from patients with pneumonia in China, 2019. N Engl J Med., ;382(8):727-733. https://doi.org/10.1056/NEJMoa2001017.

[14] African Centre for Disease Control-ACDC, 2020, Coronavirus disease 2019 (COVID-19): Africa centre for disease control. Accessed: 25 August 2020. https://africacdc.org/\%20covid-19/.

[15] Akande-Sholabi, W., Adebisi, Y.A., Bello, A., and Ilesanmi, O.S., 2020, COVID-19 in Nigeria: Is the pharmaceutical sector spared? Public Health in Practice, 1, 100044.

https://doi.org/10.1016/j.puhip.2020.100044.

[16] Nigeria Centre for Disease Control-NCDC, 2021, First case of corona virus disease confirmed in Nigeria. 28 February 2020. Retrieved 5 June 2021.

[17] Oni, B.O., 2021b, Mitigating strategies and its challenges of COVID-19 pandemic in Ogun State, Nigeria. Texila International Journal of Public Health, 1-11. DOI: 10.21522/TIJPH.2013.09.01. Art007.

[18] Nigeria Centre for Disease and Control NCDC, 2020a, COVID-19 Nigeria-Nigeria centre for disease control. Accessed: 11 August 2020. https://covid19.ncdc.gov.ng/.

[19] Thomson, L.A., et al., 2007, Systematic review of the incidence and characteristics of preventable adverse drug events in ambulatory care. Annals of Pharmacotherapy, 41(9), 1411-1426.

[20] Shanmugam, S., et al., 2011, impact of pharmaceutical care on quality of life in patients with type 2 diabetes mellitus. Journal of Royal Medical Society, 16(1), 412-418.

[21] Oni, O.B., 2021a, Cost-effectiveness analysis during lockdown and health belief model of COVID-19 pandemic in Ogun State, South-western 
Nigeria. Texila International Journal of Public Health, 1-11.

[22]Erah, P.O., and Nwazuoke, J.C., 2002, Identification of standards for pharmaceutical care in Benin City. Tropical Journal of Pharmaceutical Research, 1(2), 55-66.

[23] Oparah, C.A., and Eferakeya, A.E., 2005, Attitude of Nigerian pharmacists towards pharmaceutical care. Pharmacy World and Science, 27(3), 208-214.

[24] David, K.B., and Adebisi, Y.A., 2020, Proposed model for hospital and community pharmacy services during COVID-19 pandemic in Nigeria. Int. J. Pharm. Pract. (2020 Jul 4). https://doi.org/10.1111/ijpp.12652,10.1111/ijpp.126 52.

[25] Ashiru-Oredope, D., Chan, A.H.Y., Olaoye, O., Rutter, V., Babar, Z. and the C.P.A. COVID-19 Action Team, 2020, Needs assessment and impact of COVID-19 on pharmaceutical professionals in 31 commonwealth countries. J of Pharm Policy and Pract 13, 72, 1-11. https://doi.org/10.1186/s40545020-00275-7.

[26] Ayati, N., Saiyarsarai, P. \& Nikfar, S., 2020-, Short- and long-term impacts of COVID-19 on the pharmaceutical sector. DARU J Pharm Sci, 28, 799805. https://doi.org/10.1007/s40199-020-00358-5. [27] Chukwuorji J.C., and Iorfa, S.K., 2020, Commentary on the coronavirus pandemic: Nigeria. Psychological Trauma: Theory, Research, Practice, and Policy, 12(S1), S188- S190. DOI $10.1037 / \operatorname{tra} 0000786$.

[28]Ekpenyong, A., Udoh, A., Kpokiri, E., and Bates, I., 2018, An analysis of pharmacy workforce capacity in Nigeria. Journal of Pharmaceutical Policy and Practice, 11:20. https://doi.org/10.1186/s40545-018-0147-9.

[29] International Pharmaceutical Federation-IPF, 2006, Global pharmacy workforce and migration report: A call for action. The Hague: International Pharmaceutical Federation; 2006. Available from: http://www.fip.org/files/fip/HR/FIP\%20Global\%20P harmacy\%20and\%20Migration\%20report\%2007042 006.PDF.

[30] Smith, F., 2009, Private local pharmacies in low- and middle-income countries: a review of interventions to enhance their role in public health. Tropical Med Int Health. 2009, 14(3), 362-72.

[31] Stenson, B., Syhakhang, L., Eriksson, B., and Tomsom, G., 2001, Real world pharmacy: Assessing the quality of private pharmacy practice in the Lao People's Democratic Republic. Soc Sci Med. 2001, 52, 393-404.

[32] International Pharmaceutical Federation (IPF), 2015, Global pharmacy workforce intelligence: trends report. The Hague: International Pharmaceutical Federation; 2015. Available from: https://www.fip.org/files/fip/PharmacyEducation/Tr ends/FIPEd_Trends_report_2015_web_v3.pdf.

[33]Duggan, C., 2001, Primary and secondary care pharmacy. In: K. Taylor, and G. Harding (Eds.), Pharmacy practice (pp. 43-49). London and New York.

[34] Salami, A.A., Olorunfemi, J.F., and Olanrewaju, R.M., 2020, Geo-spatial analysis of rainfall amounts and rainy days using satellites and ground-based data in Nigeria. Journal of Meteorology and Climate Science, 18 (1).

[35] National Population Commission, 2016, 2016 Projected population of Federal Republic of Nigeria 2006 Population and Housing Census, Priority Tables, Vol. VII Abuja, Nigeria.

[36]Eze, T.C., Okpala, C.S., and Ogbodo, J.C., 2014, Patterns of inequality in human development across Nigeria's six geo-political zones. J Dev Ctries Stud., 4(8), 97-101.

[37] World Health Organization, 2015, Nigeria: WHO statistical profile 2015. Available from: http://www.who.int/gho/countries/nga.pdf?ua=1.

[38]Ansa, V., Ekott, J., and Bassey, E., 2008, Profile and outcome of cardiovascular admissions at the University of Uyo Teaching Hospital, Uyo: A five-year review. Niger J Clin Pr., 11(3), 290.

[39]Ukoh, V., 2007, Admission of hypertensive patients at the University of Benin Teaching Hospital. Nigeria East Afr Med J., 84(7), 329-35.

[40] Onwuchekwa, A.C., and Chinenye, S., 2010, Clinical profile of hypertension at a university teaching Hospital in Nigeria. Vasc Health Risk Manag, 6, 511-6.

[41] Chankova, S., Ha, N., Chipanta, D., Kombe, G., Onoja, A., and Ogungbemi, K., 2006, A situation 
assessment of human resources in the public health sector in Nigeria. Bethesda: USAID and Abt Associates InC; 2006. Available from: http://pdf.usaid.gov/pdf_docs/PNADH422.pdf.

Accessed 06/10/2020.

[42] Salami, A.A., 2018, Constraints to effective climate change adaptation policies and programmes in Osun State, Nigeria. Journal of Social Sciences and Humanities, 1(1), 9-14.

[43] Anol, B., 2012, Social science research: Principles, methods, and practices (2nd Edition). University of South Florida Tampa, Florida, USA. Published under the Creative Commons Attribution-
Non-Commercial-Share Alike 3.0 Unported License. 135-136. Retrieved 9th February, 2015 from http://scholarcommons.usf.edu/cgi/viewcontent.cgi? article $=1002 \&$ context $=$ oa_textbooks.

[44]Liu, Q., Luo, D., Haase, J.E., et al, 2020, The experiences of healthcare providers during the COVID-19 crisis in China: a qualitative study. The Lancet. Global health. 8(6), e790-e798.

[45] Ayanian, J.Z., 2020, Mental health needs of health care workers providing frontline COVID- 19 care. JAMA Health Forum. 2020. https://doi.org/10.1001/jamahealthforum.2020.0397 Published online April 1. 